\title{
Onto-Digital: An Ontology-Based Model for Digital Transformation's Knowledge
}

\author{
Fadwa Zaoui ${ }^{1}$ \\ ${ }^{1}$ Mohammed V University, EMI-SIWEB Team, Rabat, Morocco \\ E-mail: fadwa.zaoui@gmail.com \\ Nissrine Souissi ${ }^{1,2}$ \\ ${ }^{2}$ Ecole Nationale Supérieure des Mines de Rabat, Computer Science Department, Rabat, Morocco \\ E-mail: souissi@enim.ac.ma
}

Received: 10 July 2018; Accepted: 22 September 2018; Published: 08 December 2018

\begin{abstract}
The digital transformation of the company is a condition for the socio-economic development. Dealing with ICT integration in the enterprise, the paper's aim is the identification of the digital transformation conceptual components, required for designing a knowledge model.

To do this, a literature review is established to identify the dimensions, and their interrelations, to consider in the construction of a model, and which led to an ontologydriven model for digital transformation's knowledge.

In comparison with other models proposed in the literature, this ontology is exhaustive in terms of knowledge, adaptable to any sector of activity and scalable in terms of dimensions and relationships composing it.
\end{abstract}

Index Terms - Ontology, Dimensions, Knowledge, Model, Digital Transformation, ICT Integration.

\section{INTRODUCTION}

The latest reports on digital transformation [1] highlight an exponential trend of companies digitalization. It concerns more specifically the industrial enterprise with the industry 4.0 concept. The level of digitization of the industrial enterprise being of $33 \%$ in 2016, studies affirm that in 2 years this level will increase by $39 \%$ arriving to $72 \%$ in 2020 .

The digital transformation is therefore the cornerstone of any business development strategy. It is at the root of a socio-economic transformation, achieved by the massive adoption of ICT to generate, process and share information [2]

In the enterprise context, digital transformation is the integration of ICT in; the value chain, the supply and access to the products and services provided by the company.

The reflection on the digital transformation can be organized on three main axes, which the following questions express: Why to digitize a company? What are the dimensions to consider when digitizing a company? And how to digitize a company?

Numerous papers have examined the why of the digitalization of the company, mainly supporting the strong socio-economic impact of the digital transformation, of which $[3,4]$.

As for the remaining questions, of what and how of digitalize a company, and because of the urgency and the need to follow the companies digital transformation impulse, this paper proposes to look into these two questions in order to propose a knowledge model that represents all the dimensions related to digital transformation.

A literature review allowed identifying the different paths of digital transformation, through ICT integration models. In fact, various prototypes are proposed in the studied papers, most of them are adjusted to a particular sector. From these models inventory, we have been able to identify the main pillars of the digital transformation, and also detect a kind of complementarity between these models, insofar as each of these models tackles the digital transformation with a specific vision. Precisely, the reflection on this transformation is often established according to a distinct nail of sight and delimited by the nature of the activity, which is not of less importance. However, it is necessary to consider the digital transformation, outside sectoral limitations, as an economic development model by identifying all the conceptual components that can directly or indirectly impact digitalization, and thus to study the possibilities of designing a digital transformation knowledge model.

In this paper, we have relied on the analysis of the existing literature dealing with digital transformation, whether in a generic way, or of the three main branch of activity, namely education, health and industry in order to build a digital transformation knowledge model adaptable to the activity area targeted by digitalization.

The proposed model is based on an ontology representing the knowledge of digital transformation, in order to guide ICT integration in the company. This ontology, adjustable to any activity area, includes the fundamental pillars of digitalization.

The opportunity of this ontology, in comparison with other approaches of digital transformation models, is the exhaustiveness of the conceptual components composing 
it. This is what supports its generic character and extends its exploitation possibilities.

Targeting the design of a digital transformation knowledge model, this paper is organized into 7 sections. The second section deals with the literature review. The third, is about building methodology of the knowledge model to prepare the identification of digitalization's knowledge of the fourth section and the construction of the digital transformation knowledge model introduced in the fifth section. The sixth and seventh section presents the research synthesis, conclusion and perspectives of this work.

\section{LITERATURE REVIEW}

In order to devote a generic reflection on digital transformation knowledge model, we relied on a literature review, targeting ICT integration models in different sectors of activity, and motivated by the hereafter research question; what are the digital transformation models proposed by the literature?

The models we met include a significant number of methods, concepts and assumptions that we have collected and organized by business sector in order to optimize the data analysis and the knowledge extraction in relation with the digital question.

The digitization of the education sector is one of the concrete cases that have followed the exponential pace of ICT evolution and use. E-Education aims to improve / create new learning processes, so current education reforms focus on integrating ICT into the school through strategic plans for ICT adoption, development and innovation $[5,6]$.

Several models are therefore proposed by the literature, varying in the approach adopted for the integration of ICT in schools, but there are many fundamental components towards which these models converge, among others, the pedagogic, technological or cultural axis $[7,8]$.

The same goes for e-Health, this concept has emerged post-deployment of ICT in the health sector, and aimed to improve medical services and the patient's quality of life, which means, diagnosis, treatment, prevention against diseases, etc. [9]. The technological opportunity has been seized to inject a particular dynamism into health systems currently designed on the basis of ICT adoption. This is confirmed by the identified models, which focus, inter alia, on technological, informational and other components.

As for the industry sector, the new impetus of digitization that knows this sector is unique. The digitization of the factory, or the industry 4.0, is an industrial revolution allowing innovation, cost reduction, a better cover of needs, optimal solutions, intelligent systems and alternatives to the production on demand [10].

ICT integration in the industrial enterprise has implied major transformations including; the establishment of global networks integrating machines, warehouses and means of production involving intelligent machines, storage systems and production facilities capable of exchanging information, triggering actions and selfcontrolling [10].

ICT integration models identified vary according to the axes constituting them, including; technological, organizational, informational, etc.

Though this sectorial organization of ICT integration models identified in the literature, we were able to identify the main dimensions / knowledge proposed by each sector of activity. We have subsequently ranked them by level of abstraction as presented in the following sections.

The literature review, not only nourished our thinking about ICT integration models, but also provided a point of reference to assess the paper's study and to evaluate its contribution and scope.

We review in the following some examples of ICT integration approaches covering the pioneering business sectors of development, namely: education, health and industry.

\section{A. Education}

ICTs enable us to create, collect, store and use knowledge and information, to connect people and resources around the world, to contribute in knowledge creation, to share and to benefit from knowledge (ICT in the primary school, Learning and teaching with ICT, 2002). ICT integration in schools has been able to improve the quality of teaching and learning. However, it is a complex process involving fundamental changes. There are, moreover, different methodologies for ICT adoption in schools [11] presenting all considerable challenges.

In the paper [12], the key components of a generic model guiding ICT integration in education are pedagogy, social interaction and technology. The educational system is thus the correlation of these dimensions [13]. Pedagogy is the set of approaches used to teach and facilitate learning. The social aspect in a learning environment involves; communication, exchange and sharing of information between individuals. As for technology, it involves ICT tools used in teaching/learning process.

Reference [7] builds his reflection on the basis of two catalytic dimensions of ICT integration in schools, namely: (i) the structural dimension, consists of the availability of ICT infrastructure, planning and support and (ii) the cultural dimensions, consists of innovation, goal setting and leadership [14].

\section{B. Health}

The medical service has been revamped in the digital transformation era. Most of the medical activity relies currently on ICT. Addressing the question of ICT integration in health is an urgent issue. Although, there is a universal reflection in this sense, carried by the World Health Organization (WHO) and the International Telecommunications Union (ITU) to raise awareness of the need for a national vision of health system and an implementation roadmap [15].

There are numerous digitalization initiatives in the 
health sector that have led to the development of interesting ICT integration models, exposing different conceptions of digitalization. We cite in the following, some examples through the keys concepts constituting these models.

Reference [16] proposes a two-dimensional model of E-health, based on E-Health infrastructure and implementation. The infrastructure includes two main aspects, which are the E-health program and the E-health support. As for the implementation, it is organized into three sub-dimensions; electronic management, access and storage of data and virtualization of patient records (electronic patient).

Reference [17] deals with the impact of digitalized products and services offer. The EQA model is inspired by the direct and indirect identified impacts and proposes to base ICT integration on the financial system, the mechanisms of access to care and the evolution of the quality of care.

As for [18], as ground of ICT integration, the following aspects are proposed; organizational, technical and social, and mainly the correlation of these dimensions.

\section{Industry}

The Industry 4.0 concept has emerged from the integration of ICT in the factory, it depends mainly on the design of a Cyber-Physics System, in order to realize a digital and intelligent factory.

The primary goal of Industry 4.0 is to design a flexible production model that offers digitalized products and services, based on real-time interactions between people, products and devices during the production process [19].

The industrial sector too, has its own models of ICT integration in the factory, among them, the BIM model that has been a reference case for this study. BIM, or 'Building Information Model' is the expression of a technological and procedural change that has emerged from the architecture, engineering, construction and operations (AECO) industry [20].
BIM is a multidimensional model based on three axes, namely:

- BIM activities or all actors and their "Deliverables".

- $\quad$ BIM steps or maturity levels of the model.

- BIM objectives or all the data needed to identify, evaluate and qualify BIM fields and steps.

BIM is a hierarchical model, where a BIM axis represents a number of correlated components. As an example, the activity axis includes three nested business fields; BIM Technology, Process and Policy (with two subdomains each: actors and deliverables):

- Technology is "the application of scientific knowledge for practical purposes" [21].

- Process is "a specific ordering of work activities with a beginning, end, and clearly identified inputs and outputs: a structure for action" [22].

- Policies are "written principles or rules to guide decision-making" [23].

Building information modelling framework represents the correlation between these activities through interactions / intersections between them.

Other models of industrial enterprise transformation are proposed in the literature in papers [24-26].

\section{KNOWLEDGE MODEL: CONSTRUCTION METHOD}

The questions guiding this paper are: What are the key dimensions of digital transformation? And, can we build a generic digital transformation model?

Two phases consisting of following sequential steps organized this study, a first one of data preparation and a second, of designing the knowledge model. Fig.1 summarizes the principal steps:

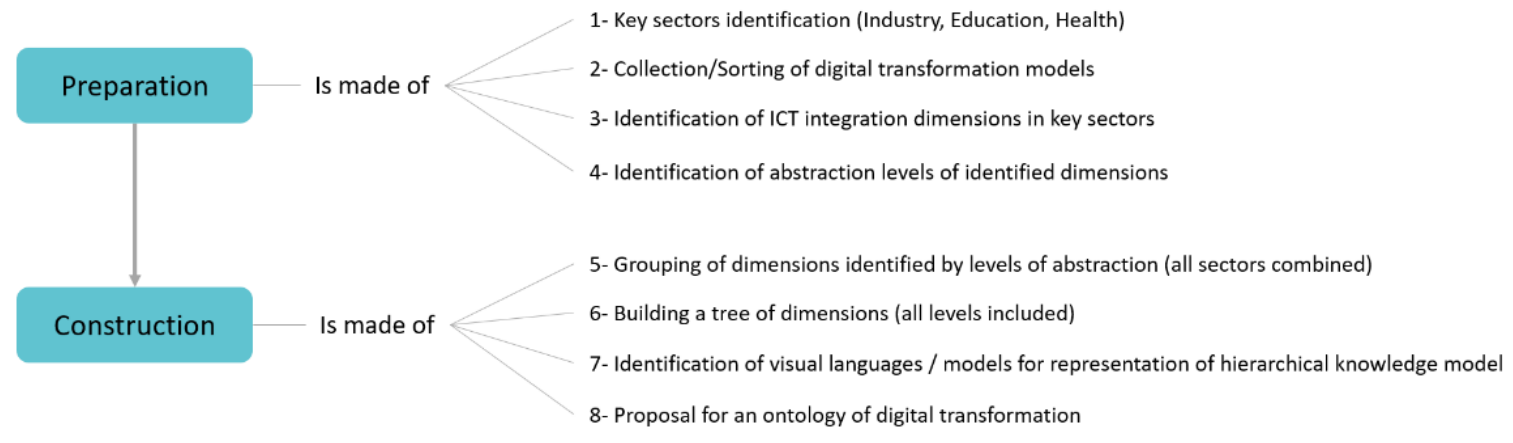

Fig.1. Knowledge model designing stages

\section{A. Key sectors identification}

The target sectors of the study include education, health, and industry, with an opening on generic integration models. The choice fell on these three sectors, being the pillars of the economic development, also of the most dynamic sectors and targets of structural change of the governments.

\section{B. Collection/Sorting of digital transformation models.}

The selected articles are taken from the following scientific databases: Google Scholar, AC DL DL, IEEE DL Xplore, Science Direct, Springer, a combination of keywords related to the digital transformation, namely, 
Multisectoral ICT integration models. These combinations are, overall: Integration Model, ICT Model, Multisectoral Integration Model, ICT Integration in Education, ICT Integration in Health, ICT Integration in Industry, Digital Transformation, and Industry 4.0.

These key words allowed locating an important number of articles that we filtered through the title and the abstract in order to extract the selection of articles summarized in Table 1.

Table $1.1^{\text {st }}$ selection of articles

\begin{tabular}{|c|c|}
\hline Sector & Number of selected articles \\
\hline Education & 15 \\
\hline Health & 19 \\
\hline Industry & 18 \\
\hline Transverse & 10 \\
\hline & 62 \\
\hline
\end{tabular}

After studying these articles, we selected for exploitation, in Table 2 the articles proposing a digital transformation approach namely:

Table 2. $2^{\text {nd }}$ selection of articles

\begin{tabular}{|c|c|}
\hline Sector & Number of selected articles \\
\hline Education & 11 \\
\hline Health & 13 \\
\hline Industry & 13 \\
\hline Transverse & 7 \\
\hline
\end{tabular}

C. Identification of ICT integration dimensions in key sectors

Based on different models proposed by the selected articles (text, prototype, paradigm, etc.) a batch of data has been collected, which represents all the identified dimensions of digital transformation.

D. Identification of abstraction levels of identified dimensions

Being the set of knowledge to be considered in ICT integration, these dimensions have been structured according to different levels of abstraction, mainly three, each one represents a particular level of detail, allowing the dimensions prioritization from more specific to more generic and vice-versa.

The arrangement of these dimensions on the basis of the three levels of abstraction allowed the construction of dimension trees by activity area. Fig. 2 illustrates this leveled organization of each business line.

E. Grouping of dimensions identified by levels of abstraction (all sectors combined)

Subsequently, dimensions of the same level of abstraction have been grouped, all sectors involved, to identify the dimensions to be selected and suggest others if necessary. Fig.3 illustrates the different dimensions of all sectors, constituting a level of abstraction.

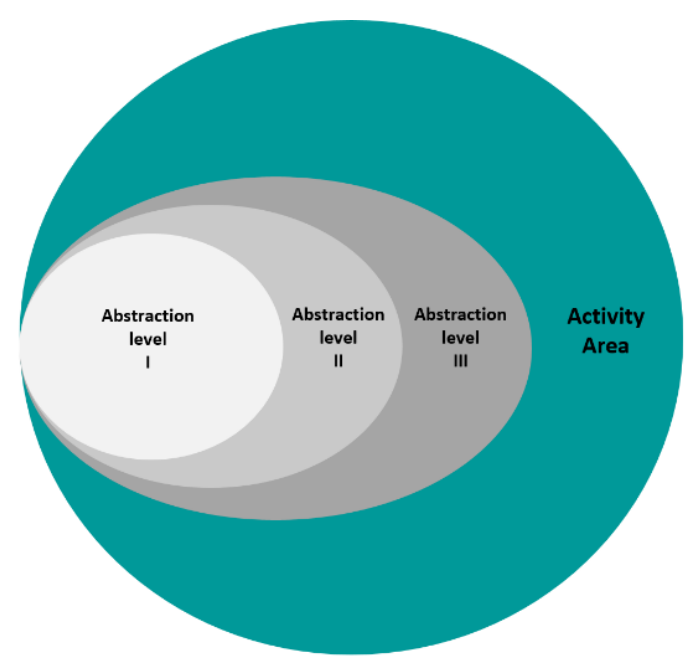

Fig.2. Grouping of identified dimensions by level of abstractions by activity area

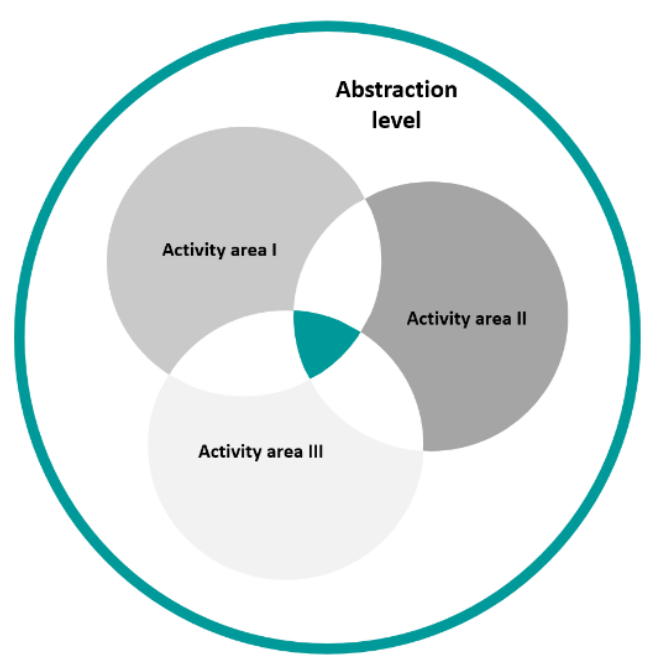

Fig.3. Grouping of identified dimensions by level of abstraction, all business activity areas involved

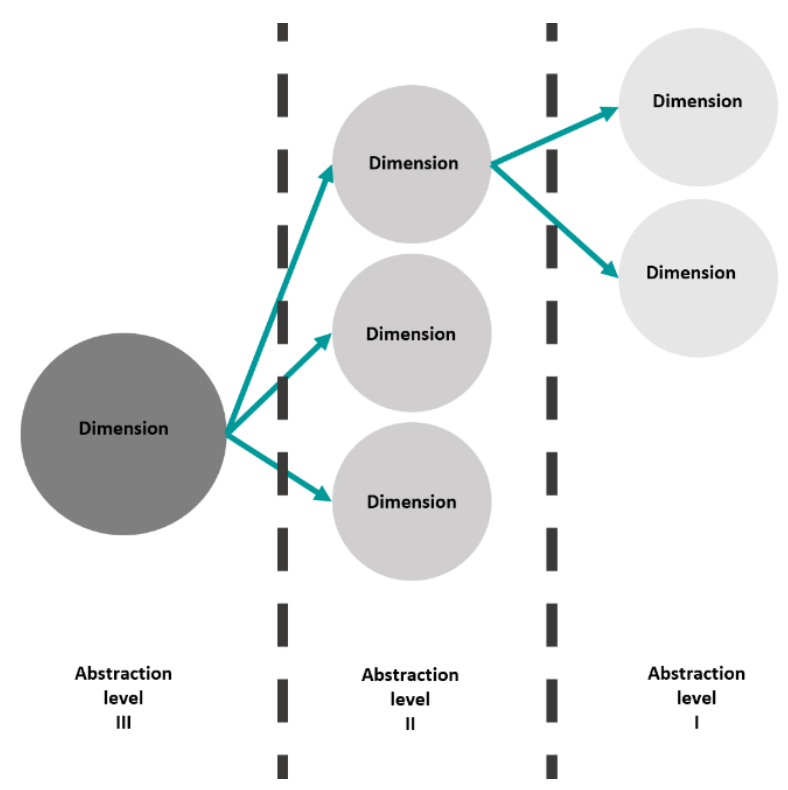

Fig.4. Hierarchical organization of abstraction levels 


\section{F. Building a tree of dimensions (all levels included)}

The chosen dimensions, by level of abstraction, are the generic dimensions found in 2 or 3 sectors or the dimensions of a particular sector that can be extrapolated to other sectors.

Three groups of dimensions have been constituted, each one representing a specific abstraction level. The hierarchical relationship structuring these groups is described in Fig.4.

G. Identification of visual languages / models for representation of hierarchical knowledge models

The original goal behind the present reflection is to support company's Digital Transformation, through the construction of a conceptual prototype that can used as a guiding model to ICT integration in various sectors of activity [27].

A model is therefore a simplified representation of knowledge, allowing a fluent portability of ideas and concepts. The points of attention relating to the construction of the model are mainly, how to inject all the data into the model and how to identify the level of simplicity/complexity of the model without disrupting its cohesion [28].

There are several modeling approaches as; visual database interfaces [29,30], graph theory [30-32] and mainly semantic approaches using domain ontologies that have been adapted for data modeling and information retrieval, [33-35]. These one have improved the interface separating the data from the queries, and thus bring the results closer to the user's search needs [30].

Representing a shared, agreed and detailed model of a specific domain [30,36] ontology offers a synergy of context-related concepts through relational links. The model that best converges with our need for conceptual representation of knowledge is ontology.

\section{H. Proposal for an ontology of digital transformation}

Primarily, the construction of ontology presupposes the selection of the appropriate language to the context of study [30]. Numerous languages have been developed, a comparative work of these languages is proposed in the paper [30]. We have chosen BIM Ontology [37] because this paper's aim is not to extract information from the ontology, but to represent from a conceptual point of view the knowledge related to digital transformation. Especially since the applicability of this language is justified by the case study conducted by Bilal Succar in his research paper [20].

\section{Digital Transformation - KNOWLEDGE CAPtURE}

The conceptual components of digital transformation identified based on the literature review of section II are presented, in this section, by level of abstraction.

The dimensions/knowledge identified by levels of abstraction have been filtered so that only those found in more than one sector are retained. Those having a generic character were also filtered out after verification of their portability/adaptability to other sectors. And this, to gather exhaustively the knowledge related to digital transformation. Table 3 includes the knowledge of the $3 \mathrm{rd}$ level of abstraction.

Table 4 includes the knowledge of the 2nd level of abstraction.

Table 5 includes the knowledge of the 1st level of abstraction.

Table 3. Digital transformation knowledge $-3^{\text {rd }}$ level of abstraction

\begin{tabular}{|c|c|}
\hline \multicolumn{2}{|c|}{ Abstraction level III } \\
\hline Dimension & Descriptive \\
\hline $\begin{array}{c}\text { Structural Dimension } \\
{[5,7,24,25,28,39,40]}\end{array}$ & $\begin{array}{l}\text { Involves changing the organizational structure, processes } \\
\text { and skills needed to exploit new technologies }\end{array}$ \\
\hline $\begin{array}{c}\text { Informational Dimension } \\
{[8,19,24,26,41-44]}\end{array}$ & Involves data/information management \\
\hline Environmental Dimension [45-47] & $\begin{array}{l}\text { Includes macro-environmental factors influencing ICT } \\
\text { integration (Regulatory Framework, Resources) }\end{array}$ \\
\hline $\begin{array}{c}\text { Security Dimension } \\
{[19,46,48,49]}\end{array}$ & $\begin{array}{c}\text { Includes; IT security (hardware, application and network), } \\
\text { data and human security and environmental security }\end{array}$ \\
\hline $\begin{array}{c}\text { Quality Dimension } \\
{[9,17,43,50]} \\
\end{array}$ & $\begin{array}{l}\text { Consists of the quality of the product and service resulting } \\
\text { from Digital Transformation }\end{array}$ \\
\hline $\begin{array}{c}\text { Financial dimension } \\
{[9,17,18,26,38,43,45,51]}\end{array}$ & Consists of investment / return on investment \\
\hline $\begin{array}{c}\text { Cultural Dimension } \\
{[7,8,52]}\end{array}$ & $\begin{array}{c}\text { Consists of all the values and behaviors shared by a } \\
\text { community / ICT Culture }\end{array}$ \\
\hline $\begin{array}{c}\text { Innovation Dimension } \\
{[5,18,38,53-56]}\end{array}$ & $\begin{array}{l}\text { Includes innovation in technology design, technology } \\
\text { processes and ICT Management }\end{array}$ \\
\hline $\begin{array}{c}\text { Participative Dimension } \\
{[12,26,47,55,57,58]}\end{array}$ & $\begin{array}{c}\text { Consists of the collaboration / interaction of any } \\
\text { stakeholder, including the user }\end{array}$ \\
\hline
\end{tabular}


Table 4. Digital transformation knowledge $-2^{\text {nd }}$ level of abstraction

\begin{tabular}{|c|c|}
\hline \multicolumn{2}{|c|}{ Abstraction level II } \\
\hline $\begin{array}{c}\text { Dimension } \\
{[5,18,19,25,50,53,59,60]}\end{array}$ & $\begin{array}{c}\text { Consists of ICT adoption, ICT deployment, } \\
\text { Dissemination, Implementation, Infusion, Integration. }\end{array}$ \\
\hline $\begin{array}{c}\text { Definition of all actions / activities after digital } \\
\text { transformation }\end{array}$ \\
\hline $\begin{array}{c}\text { Managerial Dimension } \\
{[5,16,18,19,41,43,45,50,63]}\end{array}$ & Consists of SI Management / IS Governance \\
\hline Data Management $[8,24,26,41,43,44,57,64]$ & Data management process, Collection, Sorting, \\
Analysis.
\end{tabular}

Table 5. Digital transformation knowledge $-1^{\text {st }}$ level of abstraction

\begin{tabular}{|c|c|}
\hline \multicolumn{2}{|c|}{ Abstraction level I } \\
\hline Dimension & Descriptive \\
\hline ICT integration process $[5,18,19,25,50,53,59,60]$ & $\begin{array}{c}\text { Includes steps in ICT integration, actors, } \\
\text { responsibilities and interactions }\end{array}$ \\
\hline $\begin{array}{c}\text { Work Organization and Design } \\
{[5,18,19,24,25,50,53,59]}\end{array}$ & $\begin{array}{c}\text { Reorganization of trades and responsibilities, } \\
\text { Creation of new professions }\end{array}$ \\
\hline $\begin{array}{c}\text { Responsibility for Digital Transformation } \\
\text { strategy [38] }\end{array}$ & Centralized, decentralized, ... \\
\hline Operational changes $[26,38,61,62]$ & $\begin{array}{c}\text { All changes impacting post-digitization } \\
\text { actions/activities }\end{array}$ \\
\hline Skills building [38] & Training on new jobs created by digitalization \\
\hline Leadership $[5,16,18,19,41,43,45,50,63]$ & \multirow{4}{*}{$\begin{array}{l}\text { Components of a business plan of a company in the } \\
\text { context of digital transformation }\end{array}$} \\
\hline Governance $[6,7,12,20,27,41,50,53,65]$ & \\
\hline Strategy $[5,16,18,19,41,43,45,50,63]$ & \\
\hline Management $[5,16,18,19,41,43,45,50,63]$ & \\
\hline $\begin{array}{c}\text { Technical Dimension } \\
{[5,10,18,44,48,49,50,51,56,57,66]} \\
\end{array}$ & $\begin{array}{l}\text { Includes technical infrastructure, development and } \\
\text { technical implementation }\end{array}$ \\
\hline $\begin{array}{c}\text { Technological Dimension } \\
{[5,10,12,18,19,25,26,44,46,50,54,56,57,64,67,68} \\
]\end{array}$ & $\begin{array}{c}\text { Includes Hardware, Software and Network } \\
\text { Components }\end{array}$ \\
\hline $\begin{array}{c}\text { Human Dimension } \\
{[5,18,26,45,48,51,52,54,55,69]} \\
\end{array}$ & $\begin{array}{c}\text { The social aspect: knowledge of information } \\
\text { technologies and user skills }\end{array}$ \\
\hline Legal dimension $[20,43,45,46,51]$ & $\begin{array}{c}\text { Rules governing the digital question (data } \\
\text { protection, transaction regulation) }\end{array}$ \\
\hline Political dimension $[20,43,45,46,51]$ & $\begin{array}{l}\text { General framework governing a population } \\
\text { integrating the digital movement }\end{array}$ \\
\hline
\end{tabular}

All the dimensions being collected, a first work of organization is established in order to regroup the dimensions of the same family, of all abstraction level, as proposed by the Fig.5, in preparation for the ontology presented of the next section.

\section{BUILDING KNOWLEDGE MODEL}

The design of a knowledge model requires a language representing the conceptual components identified and the relationships linking them. This section starts from 
the choice of language for this case study to the construction of the knowledge model.

\section{A. Langage - BIM ontology}

The ontological language chosen, BIM ontology, is a language derived from existing ontologies [37], the general technological ontology [70,71] and the general process ontology [65]. The re-exploitation of ontology meets the criteria of shared ontologies as explained by [72]. This language is used to represent conceptually the identified knowledge and the relationships linking them.

The BIM ontology is composed of four objects of knowledge: concepts, attributes, relationships, and sets of knowledge. The related definitions are explained in Table 6.

Table 6. BIM Ontology Knowledge Objects [15]

\begin{tabular}{|c|c|c|c|}
\cline { 2 - 4 } \multicolumn{1}{c|}{} & $\begin{array}{c}\text { Knowledge } \\
\text { Objects }\end{array}$ & Description & Examples \\
\hline I & Concepts & A mental construct & $\begin{array}{c}\text { Component; } \\
\text { Document; Role }\end{array}$ \\
\hline II & Attributes & $\begin{array}{c}\text { Values and } \\
\text { qualifiers associated } \\
\text { with Concepts }\end{array}$ & $\begin{array}{c}\text { Cost; Count; } \\
\text { Description }\end{array}$ \\
\hline III & Relations & $\begin{array}{c}\text { Connections } \\
\text { between Concepts; } \\
\text { the effect of one } \\
\text { Concept on another }\end{array}$ & $\begin{array}{c}\text { Approves; } \\
\text { Detects; } \\
\text { Supplies }\end{array}$ \\
\hline IV & Knowledge Sets & $\begin{array}{c}\text { A purposeful } \\
\text { compilation of } \\
\text { Concepts, their } \\
\text { Attributes and } \\
\text { Relations }\end{array}$ & $\begin{array}{c}\text { Knowledge } \\
\text { Foundations; Kn } \\
\text { owledge Blocks; } \\
\text { Knowledge } \\
\text { Views }\end{array}$ \\
\hline
\end{tabular}

\section{B. Objects of knowledge retained}

In order to build the digital transformation ontology, three knowledge objects of all the components of the BIM ontological language cover our need to structure the different levels of concepts identified and the relationships between them.

\section{Knowledge Set}

- Knowledge Foundations: Digital transformation ontology.

\section{Concepts}

- Knowledge domain: The set of knowledge / dimensions of digital transformation of level III.

- Component: The set of knowledge / dimensions of digital transformation of level II.

- Field: The set of knowledge / dimensions of digital transformation of level I.

- Example: Explanatory example of knowledge / dimensions of digital transformation of level I.

\section{Relations}

- Involves: It is the link of implication between the domain of knowledge and the level of knowledge III. (The domain of the digital transformation of the company, involves the set of knowledge described in the figure below, namely, structural, informational, environmental, security, quality, financial, cultural, participative \& innovation).

- Has part: represents the relationship between Level III and Level II, it is a link representing the parts making up each level III knowledge. (For example, in the digital transformation of the enterprise, the dimensions: organizational, operational and managerial are the parts composing the set of structural knowledge).

- Contains: represents the relationship between level II and level I, it is the set of knowledge of the abstraction level I contained in each knowledge of level II. (For example, in the field of digital transformation of the company, technical, technological and human resources compose the set of knowledge "Resources").

\section{Knowledge ontology}

Ontology of knowledge is representation language of a specific domain's concepts and the relations linking them. Ontologies are mainly used to standardize communication between individuals [73] and to facilitate interoperability of systems [20,74]. Ontology is also considered a preliminary stage for the construction of different domain models [73].

The ontological representation that we propose was designed on the basis of a reference model that is BIM model, resulting itself from the exploitation of "General Technological Ontology", [75] while respecting the ontology reuse criteria [72].

Our ontology, containing the four objects of knowledge; concepts, attributes, relationships and sets of knowledge (Table 6), is therefore the description of the set of knowledge identified and the relationships linking them for digital transformation. This description will enable the various stakeholders in ICT integration in the company, of any branch of activity, first to have any knowledge related directly or indirectly to digital transformation, then the possibility to analyze and exploit this knowledge to frame the digitalization of the company.

Fig.6 illustrate the Ontology-Based Model For Digital Transformation's Knowledge. 


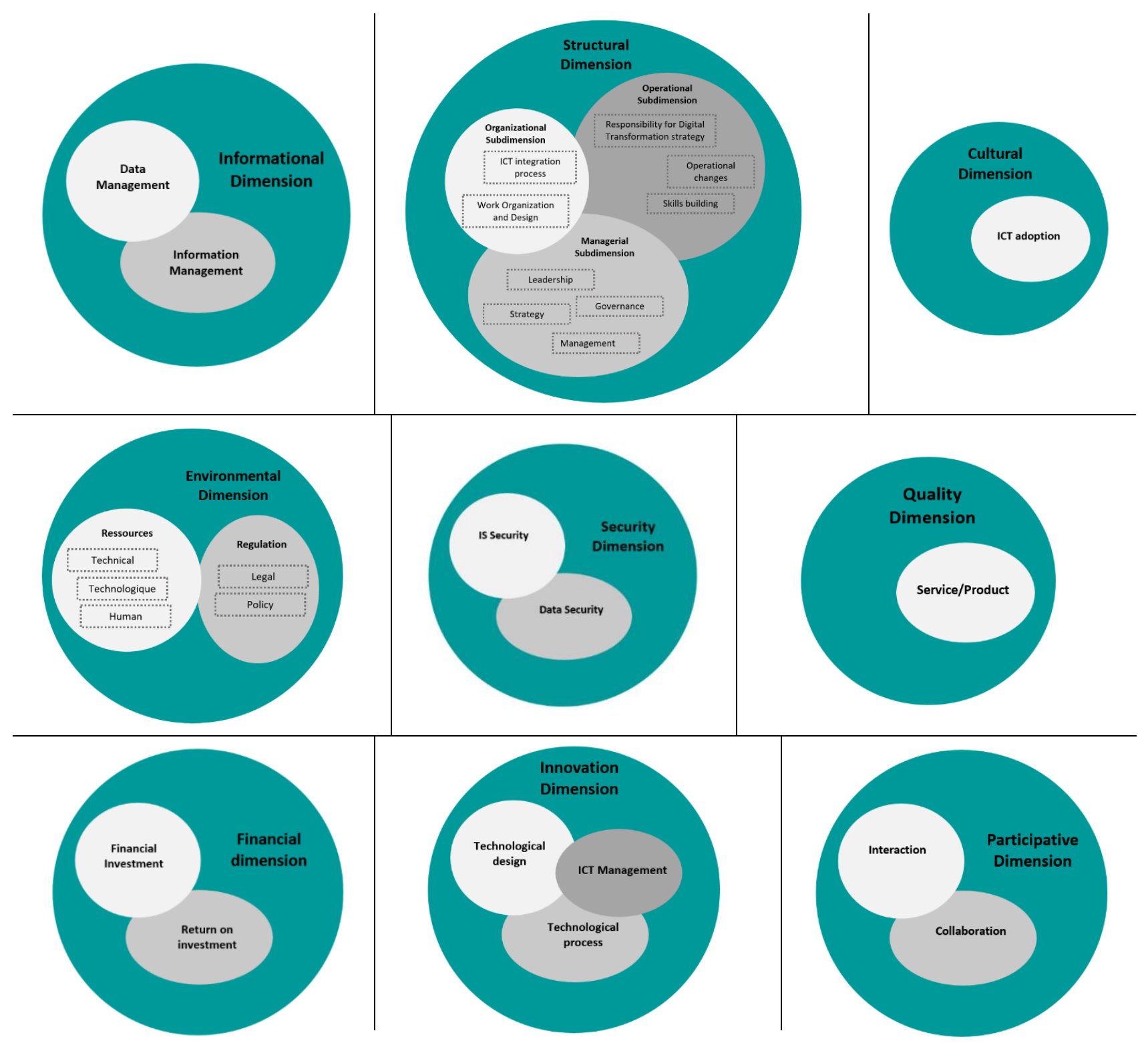

Fig.5. Group of dimensions

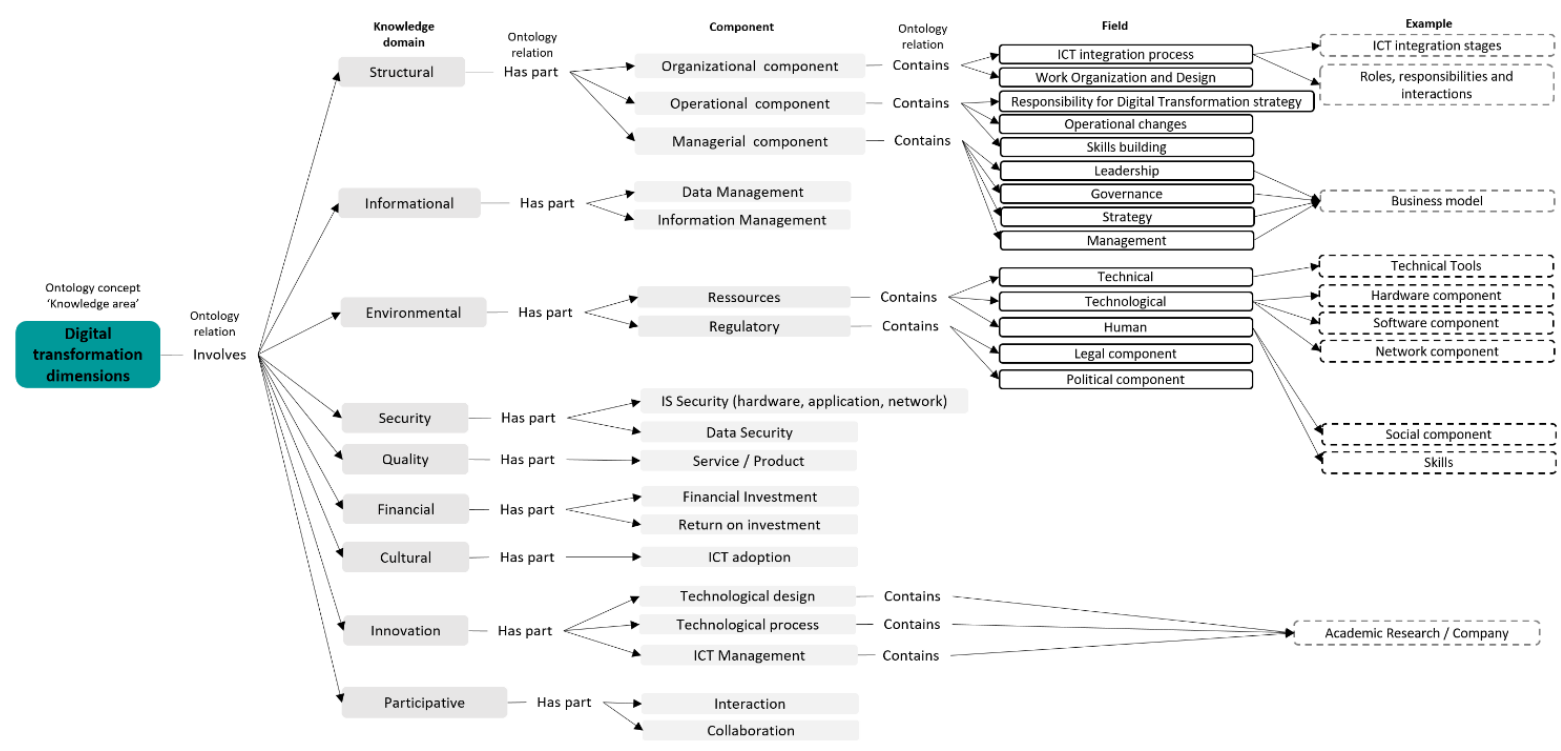

Fig.6. Ontology-Based Model for Digital Transformation's knowledge 


\section{RESEARCH SYNTHESIS}

For an optimized reflection on the digital transformation, the model we proposed in this paper includes all the knowledge identified in the literature with a hierarchical restructuring.

Considering the knowledge of the most generic level of abstraction, it is true, as already mentioned, that all these dimensions come from the literature, however, each of the studied papers covers only a number of knowledge, without the others. This can be explained by the sectorial separation in the design of ICT integration models, as well as by the variation of the approaches of studies of the digital question. A technical approach to digital transformation systematically involves a design based on technological knowledge, unlike a structural approach based on organizational, operational and managerial knowledge.

The aim of this paper is to reconcile the different conceptions of digital transformation, due to sectorial differences or to multiple study angles and perspectives, in order to propose a generic transformation approach, adaptable to the different contexts, exhaustive and based on complete knowledge.

In the histogram of Fig.7, we evaluated the presence rate of the retained dimensions, presented in the ontology (Fig.6), in the papers studied. As pictured in Fig.8 that the knowledge mainly covered by the literature are; structural (organizational, operational, managerial), informational (data management, information management) and environmental (technical, technological and human resources). Unlike knowledge as; security, financial, quality, cultural, innovation and participatory dimensions, which are moderately to slightly covered by the literature.

It is important to mention that none of the papers studied focus its conception of ICT integration on all the knowledge necessary for a complete reflection on digitalization.

The opportunity offered by this study is; a global view of the digital transformation through all the conceptual knowledge composing it, the adaptability of the ontological model to any context and the possibility of exploiting it for the building of a multi-sectorial strategy of digitization.

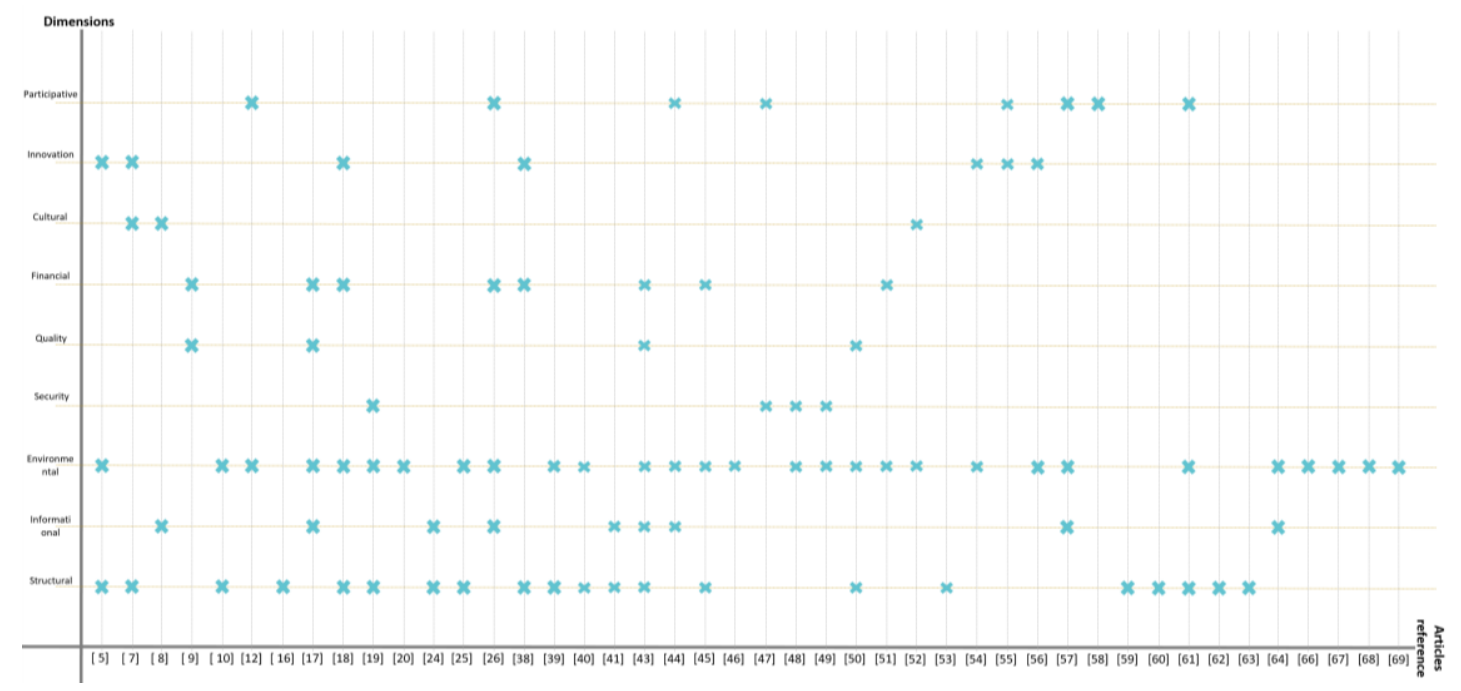

Fig.7. Correspondence between dimensions and retained article

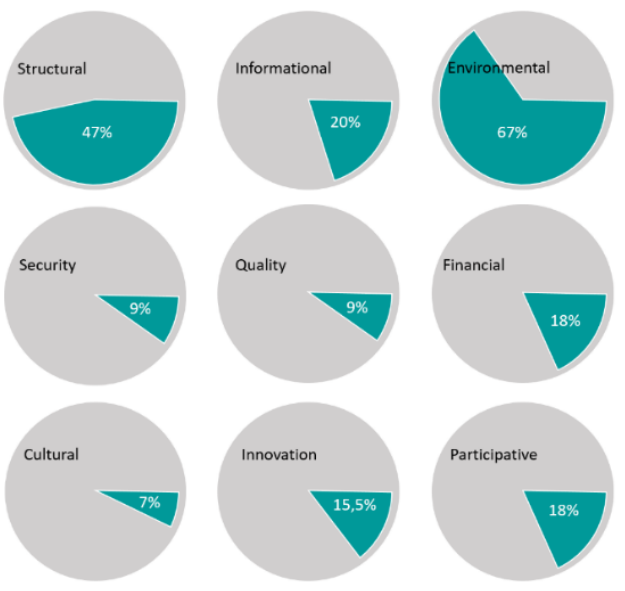

Fig.8. Percentage dimension / studied articles

\section{CONCLUSION}

Dealing with digital transformation, the paper's reflection consists of studying the dimensions required to build an ICT integration knowledge model for the company.

This work is based on a literature review that spans multiple business areas. This allowed the identification of all the conceptual components necessary to design a generic digital transformation model covering the comprehensiveness of knowledge identified in the literature.

The resulting model of this study is an ontology-based model for digital transformation's Knowledge. It is the basic tenets for any digital strategy and a guide to ICT integration in the company regardless of its sector of activity. 
Indeed, digital transformation's Knowledge is one of the two axes constituting our meta-model of digital transformation, it is also essential to evolve and complete this reflection by thinking and designing the ICT integration process in the company.

\section{REFERENCES}

[1] https://www.pwc.com/gx/en/industries/industries4.0/landing-page/industry-4.0-building-your-digitalenterprise-april-2016.pdf (Accessed: 24 May 2018)

[2] Raul Katz, Pantelis Koutroumpis, Fernando Martin Callorda, (2014) "Using a digitization index to measure the economic and social impact of digital agendas", info, Vol. 16 Issue: 1, pp.32-44, doi:10.1108/info-10-20130051

[3] Rinaldo Evangelista, Paolo Guerrieri \& Valentina Meliciani (2014) The economic impact of digital technologies in Europe,Economics of Innovation and New Technology, 23:8, 802-824, doi: 10.1080/10438599.2014.918438

[4] GUERRIERI, Paolo et BENTIVEGNA, Sara (ed.). The economic impact of digital technologies: Measuring inclusion and diffusion in Europe. Edward Elgar Publishing, 2011.

[5] YUEN, Allan HK, LAW, Nancy, et WONG, K. C. ICT implementation and school leadership: Case studies of ICT integration in teaching and learning. Journal of Educational Administration, 2003, vol. 41, no 2, p. 158170.

[6] PLOMP, Tjeerd et VOOGT, Joke. Pedagogical practices and ICT use around the world: Findings from the IEA international comparative study SITES2006. Education and information technologies, 2009, vol. 14, no 4, p. 285.

[7] TONDEUR, Jo, DEVOS, Geert, VAN HOUTTE, Mieke, et al.Understanding structural and cultural school characteristics in relation to educational change: the case of ICT integration. Educational Studies, 2009, vol. 35, no 2, p. 223-235.

[8] BENTON-BORGHI, Beatrice Hope. A Universally Designed for Learning (UDL) infused Technological Pedagogical Content Knowledge (TPACK) practitioners' model essential for teacher preparation in the 21 st Century. Journal of educational computing research, 2013, vol. 48, no 2, p. 245-265.

[9] KIERKEGAARD, Patrick. eHealth in Denmark: a case study. Journal of medical systems, 2013, vol. 37, no 6, p. 9991.

[10] SALDIVAR, Alfredo Alan Flores, LI, Yun, CHEN, Weineng, et al.Industry 4.0 with cyber-physical integration: A design and manufacture perspective. In: Automation and computing (icac), 2015 21st international conference on. IEEE, 2015. p. 1-6.

[11] BEBELL, Damian, RUSSELL, Michael, et O'DWYER, Laura. Measuring teachers' technology uses: Why multiple-measures are more revealing. Journal of Research on Technology in Education, 2004, vol. 37, no 1, p. 45-63.

[12] WANG, Qiyun. A generic model for guiding the integration of ICT into teaching and learning. Innovations in education and teaching international, 2008, vol. 45, no 4, p. 411-419.

[13] KIRSCHNER, Paul, STRIJBOS, Jan-Willem, KREIJNS, Karel, et al. Designing electronic collaborative learning environments. Educational technology research and development, 2004, vol. 52, no 3, p. 47.

[14] DEVOS, Geert, BOUCKENOOGHE, D., ENGELS, N., et al. An assessment of well-being of principals in Flemish primary schools. Journal of Educational Administration, 2007, vol. 45, no 1, p. 33-61.

[15] https://www.itu.int/en/ITU-D/ICT-

Applications/eHEALTH/Pages/NeHSToolkit.aspx

(Accessed: 25 May 2018)

[16] BOUAMRANE, Matt-Mouley et MAIR, Frances. An overview of electronic health systems development \& integration in Scotland. In: Proceedings of the first international workshop on Managing interoperability and complexity in health systems. ACM, 2011. p. 59-62. 24.

[17] HEALY, J. C. Integration of Informatic and Communication Technologies (ICT) in the EU national health systems: status and trends. Swiss Medical Informatics, 2004, vol. 20, no 52, p. 3-6.

[18] CRESSWELL, Kathrin et SHEIKH, Aziz. Organizational issues in the implementation and adoption of health information technology innovations: an interpretative review. International journal of medical informatics, 2013, vol. 82, no 5, p. e73-e86.

[19] ZHOU, Keliang, LIU, Taigang, et ZHOU, Lifeng. Industry 4.0: Towards future industrial opportunities and challenges. In: Fuzzy Systems and Knowledge Discovery (FSKD), 2015 12th International Conference on. IEEE, 2015. p. 2147-2152.

[20] SUCCAR, Bilal. Building information modelling framework: A research and delivery foundation for industry stakeholders. Automation in construction, 2009, vol. 18 , no 3, p. 357-375.

[21] Oxford, Technology - Compact Oxford English Dictionary,

http://www.askoxford.com/concise_oed/technology?view $=\mathrm{uk}$, last accessed 15 April 2007.

[22] Process Innovation: reengineering work through information technology, Harvard Business School Press, 1992.

[23] Clemson, Definition of Policy, Clemson University Office of Research Compliance, Definitions of Research Compliance Terms, 2007, Last accessed 14 April 2007, from

http://www.clemson.edu/research/orcSite/orcIRB_DefsP.h tm

[24] DE BRUYN, Peter, MANNAERT, Herwig, VERELST, Jan, et al.Enabling Normalized Systems in PracticeExploring a Modeling Approach. Business \& Information Systems Engineering, 2018, vol. 60, no 1, p. 55-67.

[25] SKINNER, Harvey A., MALEY, Oonagh, et NORMAN, Cameron D. Developing internet-based eHealth promotion programs: the Spiral Technology Action Research (STAR) model. Health Promotion Practice, 2006, vol. 7, no 4, p. 406-417.

[26] BOWERSOX, Donald J., CLOSS, David J., et DRAYER, Ralph W. The digital transformation: technology and beyond. Supply Chain Management Review, 2005, vol. 9, no 1, p. 22-29.

[27] MINSKY, Marvin. A framework for representing knowledge. 1974.

[28] RITTER, Helge. Models as Tools to Aid Thinking. In: Towards a Theory of Thinking. Springer, Berlin, Heidelberg, 2010. p. 347-374.

[29] ZHANG, Guo-Qiang, SIEGLER, Trish, SAXMAN, Paul, et al.VISAGE: a query interface for clinical research. Summit on Translational Bioinformatics, 2010, vol. 2010, p. 76.

[30] MUNIR, Kamran et ANJUM, M. Sheraz. The use of ontologies for effective knowledge modelling and information retrieval. Applied Computing and Informatics, 
2017.

[31] DAMLJANOVIC, Danica, AGATONOVIC, Milan, et CUNNINGHAM, Hamish. FREyA: An interactive way of querying Linked Data using natural language. In: Extended Semantic Web Conference. Springer, Berlin, Heidelberg, 2011. p. 125-138.

[32] FAN, Ju, LI, Guoliang, et ZHOU, Lizhu. Interactive SQL query suggestion: Making databases user-friendly. In: Data Engineering (ICDE), 2011 IEEE 27th International Conference on. IEEE, 2011. p. 351-362.

[33] PATON, Norman W., STEVENS, Robert, BAKER, Pat, et al.Query processing in the TAMBIS bioinformatics source integration system. In: Scientific and Statistical Database Management, 1999. Eleventh International Conference on. IEEE, 1999. p. 138-147.

[34] MEŠTROVIĆ, Ana et CALİ, Andrea. An ontology-based approach to information retrieval. In: Semanitic Keywordbased Search on Structured Data Sources. Springer, Cham, 2016. p. 150-156.

[35] RAMLI, Fatihah, NOAH, Shahrul Azman, et KURNIAWAN, Tri Basuki. Ontology-based information retrieval for historical documents. In: Information Retrieval and Knowledge Management (CAMP), 2016 Third International Conference on. IEEE, 2016. p. 55-59.

[36] GRUBER, Thomas R. A translation approach to portable ontology specifications. Knowledge acquisition, 1993, vol. 5, no 2, p. 199-220.

[37] http://www.bimframework.info/2015/08/bimontology.html (Accessed: 16 April 2018).

[38] HESS, Thomas, MATT, Christian, BENLIAN, Alexander, et al. Options for Formulating a Digital Transformation Strategy. MIS Quarterly Executive, 2016, vol. 15, no 2.

[39] MATT, Christian, HESS, Thomas, et BENLIAN, Alexander. Digital transformation strategies. Business \& Information Systems Engineering, 2015, vol. 57, no 5, p. 339-343.

[40] HANELT, Andre, PICCININI, Everlin, GREGORY, Robert Wayne, et al. Digital Transformation of Primarily Physical Industries-Exploring the Impact of Digital Trends on Business Models of Automobile Manufacturers In: Wirtschaftsinformatik. 2015. p. 1313-1327.

[41] HAUX, Reinhold. Health information systems-past, present, future. International journal of medical informatics, 2006, vol. 75, no 3-4, p. 268-281.

[42] YASNOFF, William A., HUMPHREYS, Betsy L., OVERHAGE, J. Marc, et al. A consensus action agenda for achieving the national health information infrastructure. Journal of the American Medical Informatics Association, 2004, vol. 11, no 4, p. 332-338.

[43] DA XU, Li, HE, Wu, et LI, Shancang. Internet of things in industries: A survey. IEEE Transactions on industrial informatics, 2014, vol. 10, no 4, p. 2233-2243.

[44] ZHAO, Jianhua et JIANG, Yinjian. Developing an Indicator System of ICT in Education: From Conceptual Model to Items Extraction. In: International Conference on Hybrid Learning and Continuing Education. Springer, Berlin, Heidelberg, 2013. p. 110-121.

[45] COLLIS, Betty et VAN DER WENDE, Marijk. Models of technology and change in higher education: An international comparative survey on the current and future use of ICT in higher education. 2002.

[46] HERMANN, Mario, PENTEK, Tobias, et OTTO, Boris. Design principles for industrie 4.0 scenarios. In: System Sciences (HICSS), 2016 49th Hawaii International Conference on. IEEE, 2016. p. 3928-3937.

[47] ZUEHLKE, Detlef. SmartFactory - Towards a factory-ofthings. Annual Reviews in Control, 2010, vol. 34, no 1, p.
129-138.

[48] GOROLL, Allan H., SIMON, Steven R., TRIPATHI, Micky, et al. Community-wide implementation of health information technology: the Massachusetts eHealth Collaborative experience. Journal of the American Medical Informatics Association, 2009, vol. 16, no 1, p. 132-139.

[49] TSIKNAKIS, Manolis et KOUROUBALI, Angelina. Organizational factors affecting successful adoption of innovative eHealth services: A case study employing the FITT framework. International journal of medical informatics, 2009, vol. 78, no 1, p. 39-52.

[50] BLUMENTHAL, David. Stimulating the adoption of health information technology. New England journal of medicine, 2009, vol. 360, no 15, p. 1477-1479.

[51] KARAGIORGI, Yiasemina et CHARALAMBOUS, Kyriacos. Curricula considerations in ICT integration: Models and practices in Cyprus. Education and Information Technologies, 2004, vol. 9, no 1, p. 21-35.

[52] COLEMAN, Katie, AUSTIN, Brian T., BRACH, Cindy, et al. Evidence on the chronic care model in the new millennium. Health affairs, 2009, vol. 28, no 1, p. 75-85.

[53] BIRCH, A. et IRVINE, V. Preservice teachers' acceptance of ICT integration in the classroom: applying the UTAUT model. Educational media international, 2009 vol. 46, no 4, p. 295-315.

[54] LEGNER, Christine, EYMANN, Torsten, HESS, Thomas, et al.Digitalization: opportunity and challenge for the business and information systems engineering community. Business \& information systems engineering, 2017, vol. 59, no 4, p. 301-308.

[55] ZHOU, Ji. Digitalization and intelligentization of manufacturing industry. Advances in Manufacturing, 2013, vol. 1, no 1, p. 1-7.

[56] BRETTEL, Malte, FRIEDERICHSEN, Niklas, KELLER, Michael, et al. How virtualization, decentralization and network building change the manufacturing landscape: An Industry 4.0 Perspective. International Journal of Mechanical, Industrial Science and Engineering, 2014, vol 8, no 1, p. 37-44.

[57] GORECKY, Dominic, SCHMITT, Mathias, LOSKYLL, Matthias, et al. Human-machine-interaction in the industry 4.0 era. In: Industrial Informatics (INDIN), 2014 12th IEEE International Conference on. Ieee, 2014. p. 289-294.

[58] MAIR, Frances S., MAY, Carl, O'DONNELL, Catherine, et al. Factors that promote or inhibit the implementation of e-health systems: an explanatory systematic review. Bulletin of the World Health Organization, 2012, vol. 90 , p. 357-364.

[59] HORLACH, Bettina, DREWS, Paul, et SCHIRMER, Ingrid. Bimodal IT: Business-IT alignment in the age of digital transformation. Multikonferenz Wirtschaftsinformatik (MKWI), 2016, p. 1417-1428.

[60] SENDALL, Shane et KOZACZYNSKI, Wojtek. Model transformation: The heart and soul of model-driven software development. IEEE software, 2003, vol. 20, no 5 , p. $42-45$.

[61] CHANIAS, Simon et HESS, Thomas. Understanding Digital Transformation Strategy formation: Insights from Europe's Automotive Industry. In: PACIS. 2016. p. 296.

[62] PAULUS-ROHMER, Dominik, SCHATTON, Heike, et BAUERNHANSL, Thomas. Ecosystems, Strategy and Business Models in the age of Digitization-How the Manufacturing Industry is Going to Change its Logic. Procedia CIRP, 2016, vol. 57, p. 8-13. 
[63] LEE, Jay, BAGHERI, Behrad, et KAO, Hung-An. A cyber-physical systems architecture for industry 4.0-based manufacturing systems. Manufacturing Letters, 2015, vol. 3 , p. $18-23$.

[64] Cottam, H. (1999). Ontologies to Assist Process Oriented Knowledge Acquisition (Draft): SPEDE, Rolls-Royce plc 1999 covered by SPEDE IPR agreement.

[65] SAHAY, Sundeep, MONTEIRO, Eric, et AANESTAD, Margunn. Configurable politics and asymmetric integration: Health e-infrastructures in India. Journal of the Association for Information Systems, 2009, vol. 10, no 5, p. 4.

[66] WANG, Qiyun et WOO, Huay Lit. Systematic planning for ICT integration in topic learning. Educational technology \& society, 2007, vol. 10, no 1, p. 148-156.

[67] JIMOYIANNIS, Athanassios. Designing and implementing an integrated technological pedagogical science knowledge framework for science teachers professional development. Computers \& Education, 2010, vol. 55, no 3, p. 1259-1269.

[68] ÇAPUK, Suat. ICT Integration models into middle and high school curriculum in the USA. Procedia-Social and Behavioral Sciences, 2015, vol. 191, p. 1218-1224.

[69] Milton, N. R. (2007a). Knowledge Acquisition in Practice: A Step-by-step Guide: Springer, London.

[70] Milton, N. R. (2007b). Specification for the General Technological Ontology (GTO). http://www.pcpack.co.uk/gto/notes/files/GTO\%20Spec\%2 0v4.doc

[71] Gruber, T. R. (1995). Toward principles for the design of ontologies used for knowledge sharing? International journal of human-computer studies, 43(5-6), 907-928.

[72] R. Studer, V.R. Benjamins, D. Fensel, Knowledge engineering: principles and methods, Data \& Knowledge Engineering

[73] M. Uschold, Building ontologies: towards a unified methodology, expert

[74] N.R. Milton, Knowledge Acquisition in Practice: A Stepby-step Guide, N.R. Milton, Specification for the General Technological Ontology (GTO)

\section{Authors' Profiles}

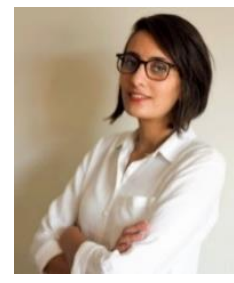

Fadwa Zaoui is a $\mathrm{PhD}$ student at Mohammed V University, Morocco and an IT project manager. She obtained an engineer degree in computer engineering from MINES-RABAT School, Morocco in 2013. Her research interests focuses on digital transformation, ICT integration and management process.

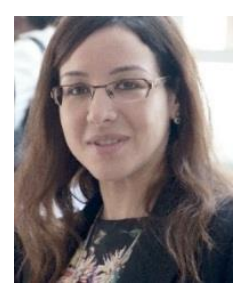

Nissrine Souissi is a fulltime professor at the MINES-RABAT School, Morocco. She obtained a $\mathrm{PhD}$ in computer science from the University of Paris XII in 2006, France and an engineer degree in computer engineering from Mohammadia School of Engineers in 2001, Morocco. Her research interests include process engineering, business process management, databases, data lifecycle, smart data, hospital information system, and information system.
How to cite this paper: Fadwa Zaoui, Nissrine Souissi, "OntoDigital: An Ontology-Based Model for Digital Transformation's Knowledge", International Journal of Information Technology and Computer Science(IJITCS), Vol.10, No.12, pp.1-12, 2018. DOI: 10.5815/ijitcs.2018.12.01 